\title{
EFFECT OF DIFFERENT LEVELS OF DIETARY CRUDE PROTEIN AND METABOLIZABLE ENERGY ON PRODUCTIVE PERFORMANCE OF LOCAL SINAI POULTRY STRAIN DURING THE GROWING PERIOD AND SUBSEQUENT LAYING PERFORMANCE
}

\author{
M.M. Beshara , Kout Elkloub, M.El.Moustafa, M.A.A. Hussein, M.G. Kasim and A.A.A. \\ Rehan
}

Anim. Prod. Res. Institute, Agric. Res. Center, Ministry of Agric. Dokki, Giza

\section{SUMMARY}

\begin{abstract}
A total number of 198 local Sinai birds (180 $q$ and 18 ^) 14-weeks-old were weighed and divided into six dietary treatments to determine the nutritional requirements of crude protein $(\mathrm{CP})$ and metabolizable energy $(\mathrm{ME})$ on growth performance and nutrients digestibility during the growing period (13-18 weeks of age) and subsequent effect during laying period from 23 to 32 weeks of age. The dietary levels of CP and ME included 3x2 factorial design (13, 14 and $15 \mathrm{CP}$, each contained 2650 and 2700 $\mathrm{ME}$ ). The results obtained indicated that $\mathrm{BW}$ at the end of grower period increased significantly with the diet contained $15 \% \mathrm{CP}+2700 \mathrm{Kcal} / \mathrm{Kg}$ diet followed by those fed diet contained $14 \% \mathrm{CP}+2650 \mathrm{Kcal} / \mathrm{Kg}$ diet as compared to the other dietary groups. The best value of feed conversion ratio was observed with the diet contained $15 \% \mathrm{CP}+2700 \mathrm{Kcal} / \mathrm{Kg}$ diet followed by the diet with $14 \% \mathrm{CP}+2650 \mathrm{Kcal} / \mathrm{Kg}$ diet. In respect of sexual maturity (SM) the pullets fed diet contained $14 \% \mathrm{CP}+2650 \mathrm{Kcal} / \mathrm{Kg}$ diet reached to SM at earlier age (139 days). the values of crude fiber digestibility was significantly increased in the pullets fed diet contained $14 \%+2650 \mathrm{kcal} / \mathrm{Kg}$ diet compared to those fed the diet with $15 \% \mathrm{CP}+2650 \mathrm{Kcal} / \mathrm{Kg}$ diet. The birds fed previous grower diet contained $15 \% \mathrm{CP}+2700 \mathrm{Kcal} / \mathrm{Kg}$ diet $\mathrm{ME}$ recorded significantly the highest value of feed intake compared to the other dietary treatments except for the diet with $14 \% \mathrm{CP}+2650 \mathrm{Kcal} / \mathrm{Kg}$ diet $\mathrm{ME}$ and $14 \% \mathrm{CP}+2700 \mathrm{Kcal} / \mathrm{Kg}$ diet ME. Subsequent significant effect was observed on feed conversion ratio where there was significantly improved due to the grower diet contained $14 \% \mathrm{CP}+2650 \mathrm{Kcal} / \mathrm{Kg}$ diet ME compared to the other treatments except for the grower diet included $\mathrm{CP} 15 \%+2700 \mathrm{Kcal} / \mathrm{Kg}$ diet. The most remarkable was observed with the hens fed previous grower diet contained $14 \mathrm{CP} \%+\mathrm{ME} 2650$ $\mathrm{Kcal} / \mathrm{Kg}$ diet where there was a significant increase in economic efficiency compared to the other dietary treatments except for those fed grower diet with CP $15 \%+\mathrm{ME} 2700 \mathrm{Kcal} / \mathrm{Kg}$ diet. The results in the current study illustrated that the Sinai birds during the growing period (13-18 weeks of age) require 14\%dietary crude protein and $2650 \mathrm{Kcal} / \mathrm{kg}$ metabolizable energy diet to optimal performance during the growing and laying periods.
\end{abstract}

Keywords: crude protein, metabolizable energy, sexual maturity, laying performance, nutrients

\section{INTRODUCTION}

The scientific and practical feeding methods are a great importance to obtain high feed efficiency (Lesson and Summers, 2001). This would balance feed price to production ratio of each animal (Skinder et al., 2001). According to Henrichs and Steinfield (2007), feed alone contributes about 60 to $70 \%$ of the total cost of poultry production. Therefore, optimal utilization of feed and avoiding unnecessary feed wastage could be the leading factors in minimizing total cost of production. Chinrasri (2004) defined nutrient requirement as the amount of nutrients needed by animals to maintain their activities, maximize growth and feed utilization efficiency, improve laying capacity and hatchability and optimize fat accumulation.

The importance of energy level in the diets for Sinai indigenous chicken breed is quite important as dietary energy level which has an effect on feed intake, feed conversion ratio and the subsequent effect during laying period. Tadelle and Ogle (2000) reported that the energy requirement of indigenous chickens is $11.99 \mathrm{MJ}(2865 \mathrm{Kcal} / \mathrm{kg}$ diet $) \mathrm{ME} / \mathrm{kg}$. NRC (1994) recommended that the required energy in growing indigenous chicken diets should be $12.14 \mathrm{MJ}(2900 \mathrm{Kcal} / \mathrm{kg}$ diet $) \mathrm{ME} / \mathrm{kg}$. However, Payne (1990) recommended $11.46 \mathrm{MJ}(2730 \mathrm{Kcal} / \mathrm{kg}$ diet $) \mathrm{ME} / \mathrm{kg}$ during the $1-6$ weeks of growing period and $10.86 \mathrm{MJ}$ (2595 Kcal/kg diet) ME/kg DM feed during the 6-12 weeks of growing period. The diets contained high energy tends to reduce feed intake in poultry but it would not allow them to receive their 


\section{Beshara et al.}

protein requirements (Bohnsack et al., 2002). This fact introduced the term of the most proper energy to protein ratio in poultry (Sohail et al., 2003).

Protein requirements vary considerably according to age, body size, sex, breed, and the physiological state of the bird. Chemjor (1998) reported that a dietary protein level of $13 \%$ was adequate for indigenous chickens aged between 14 and 21 weeks. King'ori et al. (2003) illustrated that indigenous chickens require a protein level of $16 \%$ to optimize feed intake and growth between 14 and 21 weeks of age. Also, Ndegwa et al. (2001) showed that local chickens fed diets containing 17 to $23 \% \mathrm{CP}$ had similar growth rates and feed intakes, suggesting that a $17 \% \mathrm{CP}$ diet was sufficient for these chickens. However, it is important to note that excess dietary proteins also increase heat production and water consumption which increase moisture content of litter (Lesson and Summers, 2001).

The ratio between $\mathrm{CP}$ and $\mathrm{ME}$ becomes very important as it affects productivity. Because chickens can adjust their feed intake over a considerable range of feed energy levels to meet their daily energy needs, dietary energy levels are used to set the levels of other nutrients including proteins (Gonzalez-a and Pesti, 1993). Considerable differences exist in the literature concerning the level of dietary energy to protein ratio for optimal responses in chickens. Prachya et al. (1994) reported that both live weight and growth rate in indigenous chickens were optimized at a single dietary energy to protein ratio of 58.6 MJ $\mathrm{ME} / \mathrm{kg}$ protein while feed conversion ratio was optimized at a different dietary energy to protein ratio of 62.75 MJ ME/kg protein between one and 12 weeks of age.

In fact, the information on effect of dietary energy and protein levels on production variables in Sinai pullets is limited. Therefore, there is need to ascertain such responses in indigenous Sinai pullets during the growing phase (14-19 weeks of age). Knowing requirements of these nutrients will help in the formulation of diets to optimize productivity of these birds. The objective of this study was to determine the requirements of crude protein and metabolizable energy to the Sinai pullets during the rearing period from 13 to 18 weeks of age and the subsequent influence during the laying period from 21 to 32 weeks of age.

\section{MATERIALS AND METHODS}

\section{Birds and housing:}

This study was conducted at El-Serw Poultry Research Station, Animal Poultry Research Institute, Agriculture Research Center, Ministry of Agriculture, Egypt. One hundred and ninety eight Sinai birds (180 female and 18 males) 13-wks-old were randomly assigned into six treatments of equal three replicates each. The study was assigned to $2 \times 3$ completely randomized design based on three levels of crude protein $(13,14$ and 15\%) and two levels of metabolizable energy (2650 and $2700 \mathrm{Kcal} / \mathrm{kg} \mathrm{diet})$. At the onset of the experiment, birds were weighed and assigned to treatments based on body weight so that mean body weight were similar for pullets on all treatments and the birds were kept on deep litter, in an open-sided, naturally ventilated growing house and exposed to natural day length.

The body weight and change body weight was measured at 13 and 19 weeks of age and the feed consumption on a pen basis was measured during the experimental period. After weighing pullets at the end of 19 weeks of age, these pullets were continued in the same house and all treatments were fed on the same pre and layer diet to evaluate the effect of previous dietary treatments on sexual maturity and productive performance till 32 weeks of age. A daily photoperiod was $16 \mathrm{hr}$ during the laying period.

\section{Experimental parameters measured:}

\section{1-Grower and layer diets:}

Grower, pre-lay and layer diets were offered to the birds from $13-18,19-20$ and 21- 32 weeks of age, respectively. In the grower diets, six experimental diets were formulated to contain the studied energy and protein levels. The grower diets had 13, 14 and 15\% CP and each contained 2650 and 2700 $\mathrm{Kcal} / \mathrm{kg}$ diet as shown in Table 1 . At 19 to 20 week of age hens fed pre-lay diet contained $16 \%$ protein, $2750 \mathrm{Kcal} / \mathrm{Kg} \mathrm{ME}$, and $2 \%$ calcium, afterward the calcium level was evaluated from 2 to $3.2 \%$, as recommended by NRC (1994) at the period 21-32 weeks of age (Table 2).

\section{2-Nutrients digestibility and nitrogen retention:}

At 19 weeks of age 18 males were selected on the basis of the average body weight (one male per each replicate). Birds were individually housed in metabolic cages $(60 \mathrm{~cm}$ long, $50 \mathrm{~cm}$ wide and $60 \mathrm{~cm}$ high) 
and fed their respective experimental diets (Table 1), for a period of two days to allow the birds to become adapted to cages. Then, the excreta were quantitatively collected for three days and feed intake were also recorded. Any feathers or foreign debris were removed out. Then, the excreta were dried in a forced oven at $65{ }^{\circ} \mathrm{C}$ for 24 hours. Finally, the excreta were ground well and stored in plastic bags. The proximate analysis of experimental diet and the excreta were carried out according to the official methods (A.O.A.C., 1990).

\section{3-Laying period measurements:}

Body weight at the sexual maturity, average egg weight, egg mass, feed intake (per hen/ 4 weeks) through the experimental periods were recorded as well as egg quality were recorded. Laying rate and feed conversion ratio were calculated through the same periods.

\section{4-Economical efficiency:}

At the end of the study, economical efficiency for egg production was expressed as hen-production thought the study and calculated using the following equation:

Economic efficiency $(\%)=($ Net return LE/Total feed cost LE $) \times 100$

\section{Statistical analysis:}

Data were statistically analyzed using General Linear Models Procedure of the SPSS program (2008). A factorial design $3 \times 2$ was used as the following model to study the effect of main factors and interaction between protien and energy on parameters investigated as follows:

$Y i j k=\mu+T i+R j+(T R) i j+e i j$

Where :Yijk=An observation; $\mu=$ overall mean ; $\mathrm{T}=$ effect of $\mathrm{CP}$ level; $\mathrm{I}=(1,2$ and 3$)$; $\mathrm{R}=$ effect of $\mathrm{ME}$ level; $\mathrm{j}=(1$ and 2$) ; \mathrm{TR}=$ effect of interaction between $\mathrm{CP}$ and $\mathrm{ME}(\mathrm{ij}(1,2 \ldots .6)$; and ejik= Experimental error.

Differences means among treatments were subjected to Duncan’s Multiple Range- test (Duncan, 1955).

\section{Results and discussion}

\section{Body weight and Body weight gain:}

Results of Table 3 illustrated significant influence among dietary treatments which containing different levels of crude protein \% (CP) and metabolizable energy Kcal $/ \mathrm{kg}(\mathrm{ME})$ in terms of body weight (BW) and body weight gain (BWG) to Sinai pullets through the grower period from 14 to 19 weeks of age. It is clearly observed that the final $\mathrm{BW}$ and $\mathrm{BWG}$ significantly $(\mathrm{P} \leq 0.05)$ increased due to increment the dietary level of $\mathrm{CP}(15 \%)$ and $\mathrm{ME}(2700 \mathrm{Kcal} / \mathrm{kg})$ where, BWG/bird was 215.2, 228.8 and $251.5 \mathrm{~g}$ for pullets fed diets containing 13, 14 and $15 \% \mathrm{CP}$, also it was 224.4 and $239.2 \mathrm{~g} / \mathrm{pullet}$ for pullets fed diets with 2650 and $2700 \mathrm{Kcal} / \mathrm{kg}$ diet respectively at 18 weeks of age. Regarding the interaction between CP and $\mathrm{ME}$, results indicated that $\mathrm{BW}$ at the end of grower period increased significantly $(\mathrm{P} \leq 0.05)$ by using the diet contained $15 \% \mathrm{CP}+2700 \mathrm{Kcal} / \mathrm{Kg}$ diet followed by those fed diet contained $14 \% \mathrm{CP}+2650$ $\mathrm{Kcal} / \mathrm{Kg}$ diet compared to other dietary groups. While, the birds fed diets with low level of $\mathrm{CP}$ and had lower BW than other treatments. The same trend, BWG of birds fed diet with $15 \% \mathrm{CP}$ and $2700 \mathrm{Kcal} / \mathrm{Kg}$ ME recorded significantly $(\mathrm{P} \leq 0.05)$ the highest value compared to the other treatments.

\section{Feed intake, feed conversion, sexual maturity and $1^{\text {st }}$ egg weight:}

The effects of varying levels of $\mathrm{CP}, \mathrm{ME}$ and their interaction on feed intake, feed conversion ratio, sexual maturity and $1^{\text {st }}$ egg weight are showed in Table 3 . No significant $(P \leq 0.05)$ influence of dietary different levels of $\mathrm{CP}$ on feed intake. However concerning total feed intake during the grower period it is clearly observed that increment the $\mathrm{CP}$ level from 13 to $14 \%$ and $15 \%$ resulted insignificant $(\mathrm{P} \leq 0.05)$ decrease in feed intake /bird and significantly $(\mathrm{P} \leq 0.05)$ improved the feed conversion ratio by about 23.9 and $17.6 \%$ for pullets fed diets contained 15 and $14 \%$ CP compared to those fed diet with $13 \%$ respectively. Also, the results illustrated that the pullets received diets included 14 and $15 \% \mathrm{CP}$ reached to sexual maturity (SM) at earlier age (142 days) than those fed diet contained the low level of CP (13\%). On the other hand, the $1^{\text {st }}$ egg weight significantly $(\mathrm{P} \leq 0.05)$ decreases as a result from the grower diet which contained $14 / \% \mathrm{CP}$, while the diet with $15 \% \mathrm{CP}$ recorded the highest $1^{\text {st }}$ egg weight compared to the other levels of CP.

No significant effect was observed on feed intake/bird/day and feed conversion ratio due to the diets contained either 2650 or $2700 \mathrm{Kcal} / \mathrm{Kg}$ diet. Conversely, the results showed a significant $(\mathrm{P} \leq 0.05)$ 


\section{Beshara et al.}

increase in sexual maturity (SM) and $1^{\text {st }}$ egg weight with the low level of ME $(2650 \mathrm{Kcal} / \mathrm{Kg}$ diet $)$ was applied where, $\mathrm{SM}$ and $1^{\text {st }}$ egg weight were significantly decrease $(\mathrm{P} \leq 0.05)$ comparing with the diet contained $2700 \mathrm{Kcal} / \mathrm{Kg}$ diet.

Regarding the interaction between $\mathrm{CP}$ and $\mathrm{ME}$, no significant influence was detected with the different levels of $\mathrm{CP}$ and ME. However, the best value of feed conversion ratio was observed with the diet contained $15 \% \mathrm{CP}+2700 \mathrm{Kcal} / \mathrm{Kg}$ diet followed by $14 \% \mathrm{CP}+2650 \mathrm{Kcal} / \mathrm{Kg}$ diet. In respect of SM, the results showed that the pullets fed diet contained $14 \% \mathrm{CP}+2650 \mathrm{Kcal} / \mathrm{Kg}$ reached to SM at earlier age (139 days) followed by the birds received the diet contained $15 \% \mathrm{CP}+1650$ than the diet with low level of $\mathrm{CP}+2650$ or $2700 \mathrm{Kcal} / \mathrm{Kg}$ diet ME. There was a significant effect on $1^{\text {st }}$ egg weight due to the interaction between $\mathrm{CP}$ and $\mathrm{ME}$ where, the pullets fed diet contained $14 \% \mathrm{CP}+2650 \mathrm{Kcal} / \mathrm{Kg}$ diet recorded the lowest value of $1^{\text {st }}$ egg weight $(27.59 \mathrm{~g})$ followed by the $1^{\text {st }}$ egg produced by pullets fed diet included $13 \% \mathrm{CP}+2650 \mathrm{Kcal} / \mathrm{Kg}$ diet $(29.33 \mathrm{~g})$ where these values were significantly $(\mathrm{P} \leq 0.05)$ lower than the $1^{\text {st }}$ egg weight values recorded by the other dietary interaction between $\mathrm{CP}$ and ME.

The growth performance of Sinai pullets during the period from 14-19 weeks of age in the current study is agreement with the results of Tuan et al.( 2010) who reported that increasing dietary CP significantly growth performance of chicks, where body weight was closely related with protein content in the diet.

The insignificant effect on feed intake/day due to the tow levels of ME my be due to limit rang of ME in the study $(50 \mathrm{Kcal} / \mathrm{Kg}$ diet) while in other studies this range reach to $200 \mathrm{Kcal} / \mathrm{kg}$ diet for example (Kout Elkoloub et al., 2010). Lewis et al. (1994) mentioned that chickens received $1848 \mathrm{Kcal} / \mathrm{kg}$ had $9.7 \%$ higher feed intake than the bird fed $2046 \mathrm{Kcal} / \mathrm{kg}$ energy. As it is when the level ME in the diet is increased the birds satisfy their energy by decreasing feed intake where, poultry usually consume just enough food to meet their energy requirements since the control of feed intake is believed to be based primarily on the amount of energy in the diet (Nahashon et al., 2006). Increasing the dietary energy concentration leads to a decrease in feed intake and vice versa (Veldkamp et al., 2005), thus affecting growth. However, as suggested by Smith (1990), this is valid as long as the diet is adequate enough in all other essential nutrients, and that nutrient density, accessibility and palatability do not limit feed intake. Amount of feed intake in poultry depends on the level of energy in the diet; consequently, the balance of nutrients to dietary energy content is an important factor in poultry nutrition (Wu et al., 2005). On the other hand this is seems to contradict the results obtained by (Kout Elkoloub et al., 2010) who reported that the interaction between ME and CP had no significant effect on BW and BWG in Domyati duckling during the grower period.

In respect of feed conversion ratio, these results illustrated positive correlation of feed intake, feed conversion ratio with dietary energy to protein ratio levels without any reduction in feed intake further substantiates that birds ate to meet their protein requirements which were limiting with decreasing dietary $\mathrm{CP}$ levels. Some researches illustrated that feed efficiency is affected by changes in dietary energy concentration in two partially dependent pathways. Firstly, as dietary energy increases, feed efficiency is increased as less feed is taken to satisfy the energy needs of the chickens. Secondly, growth rate is improved by increasing levels of dietary energy (Dublecz et al., 1999; Plavnik et al., 1997). Novak et al. (2007) mentioned that no significant effect was observed due to different levels of CP and ME on FCR of Bovans white Leghorn during the starter and developer period. It should be mentioned that the effective level of energy is different between various breeds (Lippense et al., 2002). Pinhriro et al. (2004) noted that the dietary energy content had a significant effect on feed intake but they also suggested that this was not true in all situations. However, such improved feed efficiency due to interaction between CP14\%+ME $2650 \mathrm{Kcal} / \mathrm{kg}$ diet in the current study has been reported in previous work by Dewi et al. (2010), who noted that diets with increase energy and protein tends to accelerate growth and improve feed conversion ratio.

\section{Nutrients digestibility:}

The effects of dietary varying levels of CP, ME and their interaction on nutrients digestibility of the experimental diets are showed in Table 4. The results obtained clearly indicated that the digestion coefficient of ether extract and crude fiber tend to be significantly $(\mathrm{P} \leq 0.05)$ increase for pullets fed diet contained 14\% CP compared to those fed the diet with 13 and 15\% CP. On the other hand, ash retention was significantly decreased due to decrement the $\mathrm{CP}$ level in the diet to $13 \% \mathrm{CP}$. While the values of dry matter (DM), organic matter (OM) and nitrogen retention (NR) were nearly similar and no significant alternation were observed due to varying levels of $\mathrm{CP} \%$ in the laying grower diet. No significant response in all digestibility coefficient $\%$ of nutrients as a result from the tow levels of ME except for the nitrogen 
execration (NE) where it was significantly increased by the diet contained low level of ME (2650 $\mathrm{Kcal} / \mathrm{Kg}$ diet).

The results of interaction among varying levels of $\mathrm{CP}$ and ME did not record any response in terms of DM, OM and NR. However, it is interesting to note that the digestibility coefficient of ether extract (EE) was significantly improved with diet included $14 \% \mathrm{CP}+2700 \mathrm{Kcal} / \mathrm{Kg}$ diet compared to the diet with $15 \% \mathrm{CP}+2650$ or $2700 \mathrm{Kcal} / \mathrm{Kg}$ diet. Also, the values of crude fiber digestibility was significantly increased in the pullets fed diet contained $14 \%+2650 \mathrm{kcal} / \mathrm{Kg}$ diet compared to those fed the diet with $15 \% \mathrm{CP}+2650 \mathrm{Kcal} / \mathrm{Kg}$ diet. The same manner, NR insignificantly improved due to the diet contained $14 \% \mathrm{CP}+2650$ or $2700 \mathrm{Kcal} / \mathrm{Kg}$ diet. The result of ash retention (AR) showed that the interaction between $13 \% \mathrm{CP}$ and $2700 \mathrm{Kcal} / \mathrm{kg}$ diet resulted in a significant decrease in AR compared to the other treatments except for the diet contained $13 \% \mathrm{CP}$ and $2650 \mathrm{Kcal} / \mathrm{Kg}$ diet.

Dry matter digestibility and nitrogen retention were not significantly influenced due to the protein and energy level of the grower diet. These results are in the line with the findings of Candrawati (1999) who clarified that no difference in dry matter and protein digestibility due to a decrease in energy and protein content of the ration. Zhao et al. (2007) mentioned that amylase, trypsin and chymotrypsin activity in jejunal fluid of birds adapted to the dietary $\mathrm{CP}$ content but not to dietary ME content. The improvement in digestibility coefficient of EE, CF and AR due to the diet contained $14 \% \mathrm{CP}$ and $2650 \mathrm{Kcal} / \mathrm{Kg}$ diet may be due to CP and ME content had effects on the activity of lipase, trypsin chymotrypsin and disaccharides in pancreas or intestinal digesta of chicks, this mean that the nutrients in the diet affect the levels of endogenous digestive enzymes (Maiorka et al., 2004).

\section{Laying performance as a subsequent effect to the grower diets:}

The subsequent effect of grower dietary varying levels of $\mathrm{CP}, \mathrm{ME}$ and their interaction on egg number/hen, egg weight and egg mass are showed in Table 5. The results illustrated that the diet contained $14 \% \mathrm{CP}$ during grower period resulted in a significantly improve in egg number/hen/day (EN) and egg production\% (EP) during interval and overall periods (21 to 32 weeks of age) compared to the other two levels of $\mathrm{CP} \%$ of grower diets. In addition, the EN or EP\% were significantly increased due to the previous grower diet with $2700 \mathrm{Kcal} / \mathrm{kg}$ diet through the period from 21 to 24 weeks of age and collective period compared to the hens fed previous diet contained $2650 \mathrm{Kcal} / \mathrm{Kg}$ grower diet.

Regardless of the response to the main factors, statistical analysis revealed significant differences due to interaction between $\mathrm{CP} \%$ and $\mathrm{ME}$ where as a rule and regardless the fluctuations observed in $\mathrm{EP} \%$ during the intervals periods, the hens fed previous laying grower diet contained CP $14 \%+\mathrm{ME} 2650$ $\mathrm{Kcal} / \mathrm{Kg}$ diet produced significantly the highest EP\% followed by those fed CP $15 \%+\mathrm{ME} 2700 \mathrm{Kcal} / \mathrm{Kg}$ diet compared to the other dietary treatments. On the other hand, the hens fed grower laying diet included $\mathrm{CP} 15 \%$ + ME $2650 \mathrm{Kcal} / \mathrm{Kg}$ diet produced significantly lower EP\% than the other groups.

As to the egg weight and egg mass, the grower laying diet contained $14 \% \mathrm{CP}+2650 \mathrm{Kcal} / \mathrm{Kg}$ diet ME produced significantly higher egg weight compared to the other treatments (Table7). In fact, the egg mass closely related to egg weight and egg number thus the hens fed previous layer diet contained $14 \%$ $\mathrm{CP}+2650 \mathrm{Kcal} / \mathrm{Kg}$ diet $\mathrm{ME}$ returned the first position in egg mass compared to other experimental groups.

\section{Feed intake and feed conversion as a subsequent effect to the grower diets:}

Results in Table 6 indicated that the subsequent effect of different levels of CP showed significant influence on feed intake (g/hen/day) and feed conversion ratio during the first, second and the collective periods. It is evident that feed intake significantly increased when dietary laying grower contained $15 \%$ $\mathrm{CP}$ was applied followed by the diet with $14 \% \mathrm{CP}$. While, feed conversion ratio was significantly improved with the diet contained $14 \% \mathrm{CP}$ by about 9.96 and $6.1 \%$ as compared to the high and low levels of $\mathrm{CP}$ respectively.

The hens fed previous laying grower diet with ME $2650 \mathrm{Kcal} / \mathrm{Kg}$ was higher in feed intake than those fed the diet with ME $2700 \mathrm{Kcal} / \mathrm{Kg}$ diet during the first and collective periods. Conversely, feed conversion was significantly improved by increasing ME level in the grower diet during the first and overall periods. However, no significant influence of dietary ME levels on feed intake or feed conversion ratio during the second and third periods.

It is interesting to note that as the grower diet with CP $13 \%+\mathrm{ME} 2700 \mathrm{Kcal} / \mathrm{Kg}$ diet applied, the feed intake was significantly reduced during the all the periods of laying periods except for the third period where no significant impact of interaction between $\mathrm{CP}$ and ME on feed intake. On the other hand the hens fed previous grower diet contained CP $15 \%+$ ME $2650 \mathrm{Kcal} / \mathrm{Kg}$ diet recorded significantly the highest 


\section{Beshara et al.}

value of feed intake during the overall period compared to the other dietary treatments with exception the diet with CP 14\% +ME2650 Kcal/Kg diet and CP14\% + ME 2700Kcal/ Kg diet.

Subsequent significant effect was observed on feed conversion ratio due the interaction between $\mathrm{CP}$ and $\mathrm{ME}$ where feed conversion ratio was significantly improved when the diet during the grower period contained CP $14 \%+\mathrm{ME} 2650 \mathrm{Kcal} / \mathrm{Kg}$ diet compared to the other treatments except for the grower diet include CP $15 \%+2700 \mathrm{Kcal} / \mathrm{Kg}$ diet. Meanwhile, the worst record in feed conversion was observed with grower diet containing CP $15 \%+\mathrm{ME} 2650 \mathrm{Kcal} / \mathrm{Kg}$ diet.

The results in the current study illustrated that when the grower laying diet contained CP $14 \%$ it is necessary alter the dietary ME level to become $2650 \mathrm{Kcal} / \mathrm{Kg}$ diet as shown the results of egg mass and feed conversion ratio. On likely explanation to these results is that the improvement in nutrients digestibility during the growing period due to the diet contained CP $14 \%+\mathrm{ME} 2650 \mathrm{Kcal} / \mathrm{Kg}$ diet where there was improvement in $\mathrm{EE}, \mathrm{CF}$ digestibility and ash retention due to this level of $\mathrm{CP}$ and $\mathrm{DE}$ and eventually birds welfare as shown in Table 5. As described above, the final body weight at 19 weeks of age was increased due to the grower diet with CP $14 \%+\mathrm{ME} 2650 \mathrm{Kcal} / \mathrm{Kg}$ diet thus it could be mentioned that positive effect during the laying period as a sequent effect attributed to the moderate increment in body weight (1151.7g/pullet) which consistent with the sexual maturity. Although low dietary energy content would minimize the cost of feed per egg production unit, it should be increased to maximize benefits (Novak et al., 2004).

\section{Egg quality:}

Data obtained on the egg quality traits as a sequent influence to dietary different levels of $\mathrm{CP}$ and ME during the growing period are showed in Table 7. As a rule, no significant effect was detected among experimental dietary treatments (CP, ME and their interaction) on egg quality. However, the most pronounced sequent effect was in egg shell where, the diet during growing period which contained $\mathrm{CP}$ $15 \%$ resulted in a significant increase in shell thickness compared to the other levels of CP. This effect may be due to sequent effect on feed intake as the hens fed the diet contained CP $15 \%$ during the grower period tend to increase feed intake through the laying period.

Both shell $\%$ and shell thickness were significantly increased due to the higher level of ME in the grower diet. But, no significant differences were showed in the other egg quality traits as a subsequent effect to the different levels of ME in the diet during the growing period.

In addition, the results elucidated some significant alternations in shell $\%$ and shell thickness due to the interaction between $\mathrm{CP}$ and $\mathrm{ME}$ where, the hens fed previous grower diet contained $\mathrm{CP} 15 \%+\mathrm{ME}$ 2650 or $2700 \mathrm{Kcal} / \mathrm{Kg}$ diet produced eggs with shell thickness significantly higher than those fed the grower diet contained CP 14\%+ME $2650 \mathrm{Kcal} / \mathrm{Kg}$ diet.

\section{Economic efficiency:}

Results related to the economic efficiency (EEF) of egg production as a subsequent effect of dietary different levels of $\mathrm{CP}, \mathrm{ME}$ and their interaction during the period from 13 to 18 weeks of age are presented in Table 8 . The most remarkable is that the hens fed previous grower diet contained $\mathrm{CP} \%+\mathrm{ME}$ $2650 \mathrm{Kcal} / \mathrm{Kg}$ diet resulted in a significant increase EEF compared to the other dietary treatments except for those fed grower diet with CP $15 \%+\mathrm{ME} 2700 \mathrm{Kcal} / \mathrm{Kg}$ diet.

\section{Conclusion}

The present study has shown that a diet containing CP $14 \%+$ ME $2650 \mathrm{Kcal} / \mathrm{kg}$ diet allowed for optimal utilization of absorbed protein and energy for growth in Sinai pullets aged between 13 and 18 weeks of age and subsequent effect during the laying period from 21 to 32 weeks of age. 
Egyptian J. Nutrition and Feeds (2017), 20 (2)Special Issue

\begin{tabular}{|c|c|c|c|c|c|c|}
\hline \multirow{3}{*}{ Ingredients } & \multicolumn{6}{|c|}{ Crude protein $\%+\mathrm{ME}(\mathrm{Kcal} / \mathrm{kg}$ diet $)$} \\
\hline & \multicolumn{2}{|c|}{13} & \multicolumn{2}{|c|}{14} & \multicolumn{2}{|c|}{15} \\
\hline & 2650 & 2700 & 2650 & 2700 & 2650 & 2700 \\
\hline Yellow corn & 64.59 & 66.8 & 63.18 & 65.34 & 61.75 & 63.93 \\
\hline Soybean meal (44\%) & 12.9 & 13.5 & 16.05 & 16.64 & 19.26 & 19.78 \\
\hline Wheat brain & 15.57 & 12.75 & 13.78 & 11.07 & 12.2 & 9.38 \\
\hline Limestone & 1.47 & 1.45 & 1.45 & 1.44 & 1.44 & 1.43 \\
\hline Dicalcium phosphate & 1.27 & 1.3 & 1.26 & 1.29 & 1.25 & 1.28 \\
\hline $\mathrm{NaCl}$ & 0.29 & 0.29 & 0.29 & 0.29 & 0.29 & 0.29 \\
\hline Premix $^{1}$ & 0.3 & 0.3 & 0.3 & 0.3 & 0.3 & 0.3 \\
\hline Dl-methionine & 0.05 & 0.05 & 0.04 & 0.04 & 0.02 & 0.02 \\
\hline Sand(inert) & 3.56 & 3.56 & 3.65 & 3.59 & 3.59 & 3.59 \\
\hline Total & 100 & 100 & 100 & 100 & 100 & 100 \\
\hline \multicolumn{7}{|c|}{ Calculated nutritional values ${ }^{2}$} \\
\hline Crude protein $\%$ & 13 & 13 & 14 & 14 & 15 & 15 \\
\hline ME (Kcal / Kg) & 2650 & 2700 & 2650 & 2700 & 2650 & 2700 \\
\hline Crude fiber\% & 4.14 & 3.92 & 4.14 & 3.94 & 4.17 & 3.95 \\
\hline Crude fat $\%$ & 3.33 & 3.32 & 3.27 & 3.26 & 3.22 & 3.2 \\
\hline Calcium \% & 0.9 & 0.9 & 0.9 & 0.9 & 0.9 & 0.9 \\
\hline Av P \% & 0.38 & 0.38 & 0.38 & 0.38 & 0.38 & 0.38 \\
\hline Lysine \% & 0.63 & 0.63 & 0.63 & 0.63 & 0.63 & 0.63 \\
\hline Methionine $\%$ & 0.28 & 0.28 & 0.28 & 0.28 & 0.28 & 0.28 \\
\hline Methionine \&cystin\% & 0.51 & 0.51 & 0.51 & 0.51 & 0.51 & 0.51 \\
\hline Sodium $\%$ & 0.17 & 0.17 & 0.17 & 0.17 & 0.17 & 0.17 \\
\hline Chloride \% & 0.18 & 0.18 & 0.18 & 0.18 & 0.18 & 0.18 \\
\hline Price $(\mathrm{LE} / \mathrm{kg})^{3}$ & 3.32 & 3.35 & 3.41 & 3.45 & 3.5 & 3.54 \\
\hline
\end{tabular}

l- Each $3 \mathrm{~kg}$ of the Vit and Min. contains: Vit. A $10 \mathrm{MIU}$, Vit. D $2 \mathrm{MIU}$, Vit E $10 \mathrm{~g}$, Vit. K $2 \mathrm{~g}$, Thiamin $1 \mathrm{~g}$, Riboflavin $5 \mathrm{~g}$, Pyridoxine $1.5 \mathrm{~g}$, Niacin $30 \mathrm{~g}$, Vit. B $1210 \mathrm{mg}$, Pantothenic acid $10 \mathrm{~g}$, Folic acid $1.5 \mathrm{~g}$, Biotin $50 \mathrm{mg}$, Choline chloride $250 \mathrm{~g}$, Manganese $60 \mathrm{~g}$, Zinc $50 \mathrm{~g}$, Iron $30 \mathrm{~g}$, Copper $10 \mathrm{~g}$, Iodine $1 \mathrm{~g}$, Selenium $0.10 \mathrm{~g}$, Cobalt $0.10 \mathrm{~g}$. and carrier $\mathrm{CaCO}_{3}$ to $3000 \mathrm{~g}$.

2- According to feed composition Tables of animal and poultry feedstuffs used in Egypt (2001)

3- Price of one kg (Egyptian pound/Kg) for different ingredients: yellow corn, 2.95; Soy been meal, 6.3; Wheat bran, 2.42; Di-calcium, 4.8; limestone, 0.20; Premix, 27.0 ; Nacl,0.50 and Dl-methionine, 150.0

Table (2): Composition and analysis results of the basal pre- lay and layer diets fed to local Sinai hens throughout the experiment

\begin{tabular}{lcc}
\hline Ingredients $(\%)$ & $\begin{array}{c}\text { Pre-lay } \\
(19-20 \text { wks. })\end{array}$ & $\begin{array}{c}\text { Layer } \\
(21-32 \text { wks. })\end{array}$ \\
\hline Yellow corn & 65.09 & 64.70 \\
Soy bean meal $(44 \%)$ & 24.45 & 24.75 \\
Wheat bran & 1.70 & 1.00 \\
Di-calcium phosphate & 1.50 & 1.50 \\
Limestone & 4.70 & 7.40 \\
Vit \& Min. premix & 0.30 & 0.30 \\
Na Cl & 0.30 & 0.30 \\
DL- Methionine $(99 \%)$ & 0.05 & 0.05 \\
Sand & 1.61 & 0.00 \\
Total & 100 & 100 \\
Calculated Analysis & & \\
Crude protein $\%$ & 16.03 & 16.02 \\
ME ( Kcal / kg ) & 2748 & 2732 \\
\hline
\end{tabular}


Beshara et al.

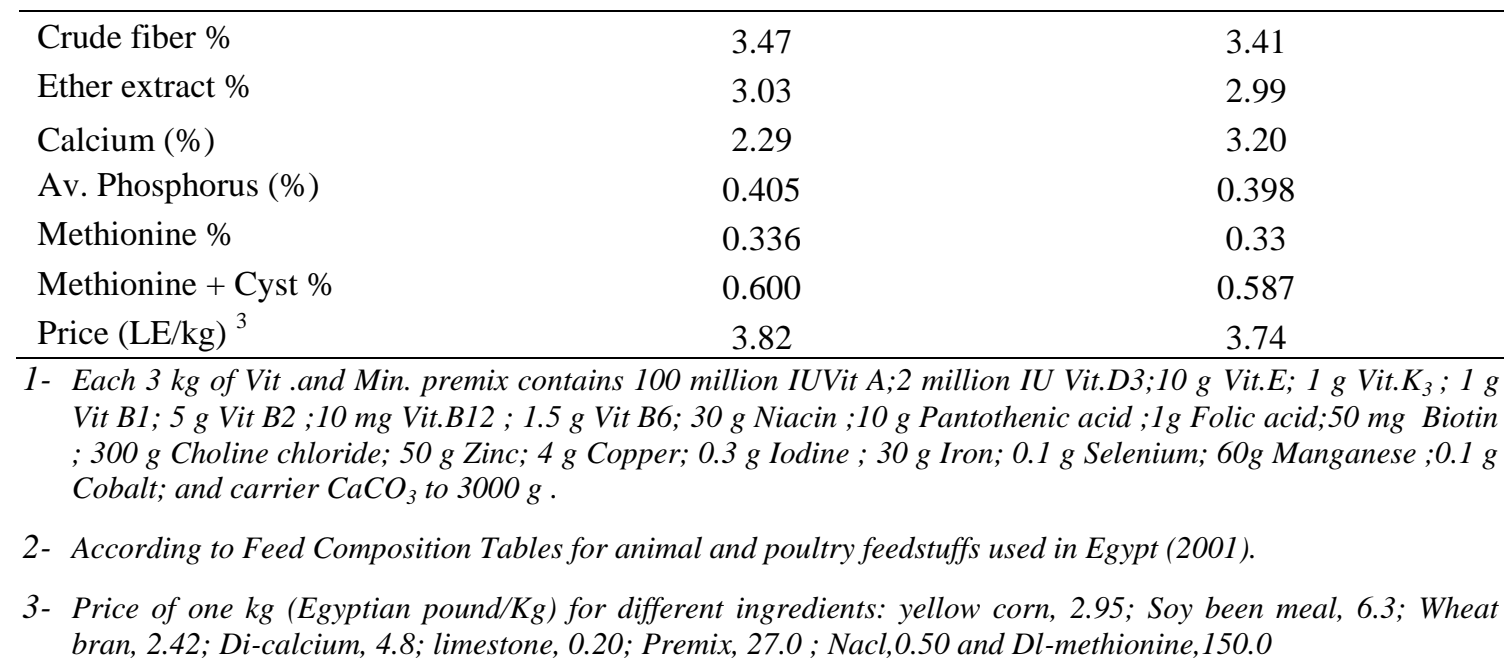

Table (3): Effect of different levels of CP and ME on growth performance of local Sinai pullets (1419 weeks of age)

\begin{tabular}{|c|c|c|c|c|c|c|c|c|}
\hline \multirow{2}{*}{\multicolumn{2}{|c|}{ Factors }} & \multicolumn{7}{|c|}{ Variables } \\
\hline & & $\begin{array}{c}\text { Initial } \\
\mathrm{BW}\end{array}$ & $\begin{array}{l}\text { Final } \\
\text { BW }\end{array}$ & $\begin{array}{c}\text { Change } \\
\text { BW }\end{array}$ & $\begin{array}{l}\text { Feed } \\
\text { intake }\end{array}$ & $\begin{array}{c}\text { Feed } \\
\text { conversion }\end{array}$ & $\begin{array}{l}\text { Sexual } \\
\text { maturity } \\
\text { (days) }\end{array}$ & $\begin{array}{l}1^{\text {st }} \text { egg } \\
\text { weight }\end{array}$ \\
\hline \multicolumn{9}{|c|}{ Crude protein $(\mathrm{CP}) \%$} \\
\hline \multicolumn{2}{|c|}{13} & 919 & $1134.2^{\mathrm{b}}$ & $215.2^{\mathrm{b}}$ & 72.12 & $14.64^{\mathrm{a}}$ & $147^{\mathrm{a}}$ & $30.65^{b}$ \\
\hline \multicolumn{2}{|l|}{14} & 917 & $1145.8^{b}$ & $228.8^{\mathrm{b}}$ & 71.53 & $12.07^{\mathrm{b}}$ & $142^{\mathrm{b}}$ & $29.58^{\mathrm{c}}$ \\
\hline \multicolumn{2}{|l|}{15} & 916 & $1167.5^{\mathrm{a}}$ & $251.5^{\mathrm{a}}$ & 71.04 & $11.14^{\mathrm{b}}$ & $142^{\mathrm{b}}$ & $31.9^{\mathrm{a}}$ \\
\hline \multicolumn{2}{|c|}{ SE mean } & 4.06 & 5.38 .0 & 6.98 & 0.65 & 0.54 & 1.07 & 0.24 \\
\hline \multicolumn{9}{|c|}{ Metabolizable energy (ME) Kcal/kg diet } \\
\hline \multicolumn{2}{|c|}{2650} & 917.7 & $1141.1^{\mathrm{b}}$ & $224.4^{\mathrm{a}}$ & 71.47 & 12.69 & $142^{\mathrm{b}}$ & $29.77^{\mathrm{b}}$ \\
\hline \multicolumn{2}{|c|}{2750} & 918 & $1157.2^{\mathrm{a}}$ & $239.2^{\mathrm{b}}$ & 71.65 & 12.53 & $144^{\mathrm{a}}$ & $31.65^{\mathrm{a}}$ \\
\hline \multicolumn{2}{|c|}{ SE mean } & 3.31 & 4.39 .0 & 5.70 & 0.53 & 0.44 & 0.88 & 0.34 \\
\hline \multicolumn{9}{|c|}{ Interaction between $\mathrm{CP}$ and $\mathrm{ME}$} \\
\hline \multirow{2}{*}{13} & 2650 & 918 & $1125.0^{\mathrm{c}}$ & $207.0^{\mathrm{b}}$ & 73.30 & $15.65^{\mathrm{a}}$ & $148^{\mathrm{a}}$ & $29.33^{\mathrm{b}}$ \\
\hline & 2700 & 920 & $1143.3^{\mathrm{bc}}$ & $223.3^{\mathrm{b}}$ & 70.94 & $13.62^{\mathrm{ab}}$ & $145^{\mathrm{ab}}$ & $31.96^{\mathrm{a}}$ \\
\hline \multirow{2}{*}{14} & 1650 & 917 & $1151.7^{\mathrm{b}}$ & $234.7^{\mathrm{b}}$ & 71.06 & $10.98^{\mathrm{c}}$ & $139^{\mathrm{c}}$ & $27.59^{c}$ \\
\hline & 2700 & 917 & $1140.0^{\mathrm{bc}}$ & $223.0^{\mathrm{b}}$ & 72.00 & $13.15^{\mathrm{bc}}$ & $144^{\mathrm{abc}}$ & $31.57^{\mathrm{a}}$ \\
\hline
\end{tabular}


Egyptian J. Nutrition and Feeds (2017), 20 (2)Special Issue

\begin{tabular}{ccccccccc}
\hline \multirow{2}{*}{15} & 2650 & 915 & $1146.7^{\mathrm{bc}}$ & $231.7^{\mathrm{b}}$ & 70.06 & $11.44^{\mathrm{bc}}$ & $140^{\mathrm{bc}}$ & $32.39^{\mathrm{a}}$ \\
& 2700 & 917 & $1188.7^{\mathrm{a}}$ & $271.3^{\mathrm{a}}$ & 72.02 & $10.83^{\mathrm{c}}$ & $144^{\mathrm{abc}}$ & $31.41^{\mathrm{a}}$ \\
\multicolumn{2}{c}{ SE mean } & 5.74 & 7.61 & 9.87 & 0.92 & 0.77 & 1.51 & 0.34 \\
\hline \multicolumn{2}{l}{ a,b,c: means in the same column bearing different superscripts are significantly different $(p \leq 0.05)$}
\end{tabular}

Table (4): Effect of different levels of CP and ME on digestibility coefficient of

nutrients of local Sinai pullets.

\begin{tabular}{|c|c|c|c|c|c|c|c|c|c|}
\hline \multirow{2}{*}{\multicolumn{2}{|c|}{ Factors }} & \multicolumn{8}{|c|}{ Digestibility coefficient } \\
\hline & & $\begin{array}{c}\text { Dry } \\
\text { matter }\end{array}$ & $\begin{array}{c}\text { Ether } \\
\text { extract }\end{array}$ & $\begin{array}{c}\text { Crude } \\
\text { fiber }\end{array}$ & $\begin{array}{c}\text { Organic } \\
\text { matter }\end{array}$ & $\mathrm{NI}^{\mathrm{I}}$ & $\mathrm{NE}^{2}$ & $\mathrm{NR}^{3}$ & $\mathrm{AR}^{4}$ \\
\hline \multicolumn{10}{|c|}{ СР \% } \\
\hline \multicolumn{2}{|c|}{13} & 71.8 & $40.3^{\mathrm{a}}$ & $22.4^{\mathrm{b}}$ & 77.0 & 2.0 & 0.86 & 56.7 & $33.7^{\mathrm{b}}$ \\
\hline \multicolumn{2}{|l|}{14} & 73.8 & $45.6^{\mathrm{a}}$ & $32.2^{\mathrm{a}}$ & 78.3 & 2.2 & 0.85 & 61.2 & $41.1^{\mathrm{a}}$ \\
\hline \multicolumn{2}{|l|}{15} & 71.5 & $34.1^{\mathrm{b}}$ & $20.6^{\mathrm{b}}$ & 76.2 & 2.1 & 0.87 & 58.6 & $42.2^{\mathrm{a}}$ \\
\hline \multicolumn{2}{|c|}{ SE mean } & 0.83 & 1.99 & 1.12 & 0.72 & 0.07 & 0.03 & 1.48 & 2.02 \\
\hline \multicolumn{10}{|c|}{ ME (Kcal/ kg diet) } \\
\hline \multicolumn{2}{|c|}{2650} & 72.6 & 39.6 & 26.0 & 77.4 & 2.16 & $0.89^{\mathrm{a}}$ & 58.2 & 39.1 \\
\hline \multicolumn{2}{|c|}{2700} & 72.2 & 40.6 & 24.2 & 76.9 & 2.03 & $0.82^{\mathrm{b}}$ & 59.4 & 38.9 \\
\hline \multicolumn{2}{|c|}{ SE mean } & 0.68 & 1.63 & 2.54 & 0.72 & 0.05 & 0.03 & 1.21 & 1.65 \\
\hline \multicolumn{10}{|c|}{ Interaction $\mathrm{CP} * \mathrm{ME}$} \\
\hline \multirow[t]{2}{*}{13} & 2650 & 71.7 & $41.6^{\mathrm{abc}}$ & $24.5^{\mathrm{ab}}$ & 76.8 & $2.0^{\mathrm{b}}$ & $0.87^{\mathrm{ab}}$ & 55.2 & $37.7^{\mathrm{ab}}$ \\
\hline & 2700 & 71.9 & $39.1^{\mathrm{abc}}$ & $20.2^{\mathrm{b}}$ & 77.2 & $2.0^{\mathrm{b}}$ & $0.84^{\mathrm{ab}}$ & 58.3 & $29.6^{\mathrm{b}}$ \\
\hline \multirow[t]{2}{*}{14} & 2650 & 74.9 & $44.4^{\mathrm{ab}}$ & $36.5^{\mathrm{a}}$ & 79.3 & $2.4^{\mathrm{a}}$ & $0.94^{\mathrm{a}}$ & 61.2 & $40.0^{\mathrm{a}}$ \\
\hline & 2700 & 72.6 & $46.8^{\mathrm{a}}$ & $28.0^{\mathrm{ab}}$ & 77.3 & $1.9^{\mathrm{b}}$ & $0.75^{\mathrm{b}}$ & 61.2 & $42.1^{\mathrm{a}}$ \\
\hline \multirow[t]{2}{*}{15} & 2650 & 71.2 & $32.6^{\mathrm{c}}$ & $16.9^{\mathrm{b}}$ & 76.2 & $2.1^{\mathrm{b}}$ & $0.86^{\mathrm{ab}}$ & 58.3 & $39.5^{\mathrm{a}}$ \\
\hline & 2700 & 71.9 & $35.7^{\mathrm{bc}}$ & $24.2^{\mathrm{ab}}$ & 76.3 & $2.1^{\mathrm{b}}$ & $0.88^{\mathrm{ab}}$ & 58.9 & $44.8^{\mathrm{a}}$ \\
\hline \multicolumn{2}{|c|}{ \pm SE mean } & 1.18 & 2.82 & 4.41 & 1.02 & 0.09 & 0.05 & 2.10 & 2.86 \\
\hline
\end{tabular}

$a, b, c:$ means in the same column bearing different superscripts are significantly different ( $p \leq 0.05)$

$N I^{I}=$ Nitrogen intake; $N E^{2}=$ Nitrogen excretion; $N R^{3}=$ Nitrogen retention $A R^{4}=$ Ash retention 
Table (5): Egg production and egg number of local Sinai hens as a subsequent effect to fed grower diets contained different levels of $\mathrm{CP}$ and ME

\begin{tabular}{|c|c|c|c|c|c|c|c|c|c|c|c|c|c|}
\hline \multirow{2}{*}{\multicolumn{2}{|c|}{$\begin{array}{l}\text { Variable } \\
\text { Factors }\end{array}$}} & \multicolumn{4}{|c|}{$\begin{array}{c}\text { Egg number/hen/d } \\
\text { Age (weeks) }\end{array}$} & \multicolumn{4}{|c|}{$\begin{array}{l}\text { Egg weight } \\
\text { Age(weeks) }\end{array}$} & \multicolumn{4}{|c|}{$\begin{array}{c}\text { Egg mass } \\
\text { Age(weeks) }\end{array}$} \\
\hline & & $21-24$ & $25-28$ & $29-32$ & 21-32 & $21-24$ & $25-28$ & 29-32 & 21-32 & 21-24 & $25-28$ & 29-32 & 21-32 \\
\hline \multicolumn{14}{|c|}{ CP \% } \\
\hline 13 & & $8.4^{\mathrm{b}}$ & $18.5^{\mathrm{c}}$ & $19.4 \mathrm{~b}$ & 46.3b & $35.7 \mathbf{b}$ & 40.5 & 44.3 & $40.2 b$ & 301.1 & 747.3c & $860.9 a$ & $1860.6^{b}$ \\
\hline 14 & & $10.7^{\mathrm{a}}$ & $19.9^{a}$ & $19.9 a$ & $50.5 a$ & 37.1a & 41.2 & 44.3 & $40.9 a$ & 394.7 & 821.0a & $882.2 a$ & $2062.8^{\mathrm{a}}$ \\
\hline 15 & & $8.8^{b}$ & $18.9^{b}$ & $18.6 c$ & $46.3 b$ & 36.8ab & 40.6 & 43.6 & 40.3b & 322.7 & $766.5 b$ & $810.9 b$ & $1866.5^{b}$ \\
\hline SE $\mathbf{r}$ & & 0.16 & 0.12 & 0.14 & 0.29 & 0.37 & 0.24 & 0.23 & 0.14 & 4.84 & 4.74 & 7.61 & 10.68 \\
\hline \multicolumn{14}{|c|}{ ME (Kcal/kg diet) } \\
\hline 2650 & & $8.30^{b}$ & 19.0 & 19.4 & $46.7^{b}$ & 36.6 & $41.2^{\mathrm{a}}$ & 44.3 & $40.7^{\mathrm{a}}$ & $305.1^{\mathrm{b}}$ & 782.0 & 860.0 & $1902.8^{b}$ \\
\hline 2700 & & $10.3^{\mathrm{a}}$ & 19.2 & 19.2 & $48.7^{\mathrm{a}}$ & 36.4 & $40.4^{b}$ & 43.9 & $40.2^{b}$ & $373.9^{\mathrm{a}}$ & 774.5 & 842.7 & $1957.1^{a}$ \\
\hline SE $\mathbf{r}$ & & 0.13 & 0.10 & 1.12 & 0.46 & 0.30 & 0.20 & 0.19 & 0.11 & 3.95 & 3.87 & 6.21 & 8.72 \\
\hline \multicolumn{14}{|c|}{ Interaction $\mathbf{C P} * \mathbf{M E}$} \\
\hline \multirow[t]{2}{*}{13} & 2650 & $8.1^{\mathrm{e}}$ & $19.0^{b}$ & $19.4^{\mathrm{b}}$ & $46.4^{\mathrm{c}}$ & 35.8 & $40.8^{b}$ & $44.8^{\mathrm{ab}}$ & $40.5^{b}$ & $288.5^{\mathrm{e}}$ & $773.8^{c}$ & $869.5^{\mathrm{b}}$ & $1878.8^{c}$ \\
\hline & 2700 & $8.8^{d}$ & $18.0^{\mathrm{c}}$ & $19.4^{\mathrm{b}}$ & $46.2^{\mathrm{c}}$ & 35.6 & $40.1^{b}$ & $43.8^{\mathrm{bc}}$ & $39.9^{b}$ & 313.8 ${ }^{\mathrm{d}}$ & $720.7^{\mathrm{d}}$ & $852.4^{\mathrm{bc}}$ & $1842.4^{\mathrm{c}}$ \\
\hline \multirow[t]{2}{*}{14} & 2650 & $11.1^{\mathrm{b}}$ & $19.9^{\mathrm{a}}$ & $20.2^{\mathrm{a}}$ & $51.2^{\mathrm{a}}$ & 37.1 & $42.0^{\mathrm{a}}$ & $44.9^{\mathrm{a}}$ & $41.3^{\mathrm{a}}$ & $412.2^{b}$ & $835.9^{a}$ & $908.2^{\mathrm{a}}$ & $2118.0^{a}$ \\
\hline & 2700 & $10.2^{\mathrm{c}}$ & $19.9^{a}$ & $19.6^{b}$ & $47.9^{b}$ & 37.0 & $40.4^{b}$ & $43.8^{\mathrm{bc}}$ & $40.4^{b}$ & $377.2^{\mathrm{c}}$ & $806.0^{b}$ & $856.2^{b}$ & $2007.6^{b}$ \\
\hline \multirow[t]{2}{*}{15} & 2650 & $5.8^{\mathrm{f}}$ & $18.1^{\mathrm{c}}$ & $18.6^{\mathrm{c}}$ & $42.5^{d}$ & 37.0 & $40.7^{b}$ & $43.1^{c}$ & $40.3^{b}$ & $214.6^{f}$ & $736.4^{d}$ & $802.4^{\mathrm{d}}$ & $1711.7^{d}$ \\
\hline & 2700 & $11.8^{\mathrm{a}}$ & $19.7^{\mathrm{a}}$ & $18.6^{c}$ & $50.0^{\mathrm{ab}}$ & 36.6 & $40.5^{b}$ & $44.1^{a b c}$ & $40.4^{b}$ & $430.8^{a}$ & $796.6^{b}$ & $819.4^{\text {cd }}$ & $2021.3^{b}$ \\
\hline \multicolumn{2}{|c|}{ SE mean } & 0.23 & 0.16 & 0.20 & 0.42 & 0.52 & 0.34 & 0.33 & 0.19 & 6.85 & 6.71 & 10.76 & 15.10 \\
\hline
\end{tabular}

Table (6): Feed intake and feed conversion of local Sinai hens as a subsequent effect to grower fed diets contained different levels of $\mathrm{CP}$ and $\mathrm{ME}$

\begin{tabular}{|c|c|c|c|c|c|c|c|c|c|}
\hline \multirow{2}{*}{\multicolumn{2}{|c|}{$\begin{array}{l}\text { Variable } \\
\text { Factors }\end{array}$}} & \multicolumn{4}{|c|}{$\begin{array}{c}\text { Feed intake/hen/d } \\
\text { Age (weeks) }\end{array}$} & \multicolumn{4}{|c|}{$\begin{array}{c}\text { Feed conversion } \\
\text { Age (weeks) }\end{array}$} \\
\hline & & $21-24$ & $25-28$ & $29-32$ & $21-32$ & $21-24$ & $25-28$ & 29-32 & $21-32$ \\
\hline \multicolumn{10}{|c|}{ Crude protein $(\mathrm{CP}) \%$} \\
\hline 13 & & $90.8^{\mathrm{b}}$ & $95.1^{\mathrm{b}}$ & 108.7 & $98.2^{\mathrm{b}}$ & $8.48^{b}$ & $3.57^{b}$ & 3.54 & $4.43^{b}$ \\
\hline 14 & & $92.9^{\mathrm{b}}$ & $102.0^{\mathrm{a}}$ & 111.5 & $102.1^{\mathrm{a}}$ & $6.61^{c}$ & $3.48^{\mathrm{c}}$ & 3.54 & $4.16^{c}$ \\
\hline 15 & & $97.6^{\mathrm{a}}$ & $101.1^{\mathrm{a}}$ & 116.7 & $101.8^{\mathrm{a}}$ & $9.16^{\mathrm{a}}$ & $3.70^{\mathrm{a}}$ & 3.69 & $4.62^{\mathrm{a}}$ \\
\hline SE & ean & 1.38 & 0.83 & 1.92 & 0.58 & 0.15 & 0.04 & 0.08 & 0.04 \\
\hline \multicolumn{10}{|c|}{ Metabolizable energy (ME) Kcal/kg diet } \\
\hline 265 & & $95.6^{\mathrm{a}}$ & 99.1 & 109.3 & $101.3^{\mathrm{a}}$ & $9.49^{\mathrm{a}}$ & 3.56 & 3.57 & $4.5^{\mathrm{a}}$ \\
\hline 270 & & $91.9^{\mathrm{b}}$ & 99.7 & 108.7 & $100.1^{\mathrm{b}}$ & $6.97^{b}$ & 3.61 & 3.62 & $4.3^{\mathrm{b}}$ \\
\hline SE & ean & 1.13 & 0.68 & 1.57 & 0.48 & 0.12 & 0.03 & 0.07 & 0.04 \\
\hline \multicolumn{10}{|c|}{ Interaction between $\mathrm{CP} * \mathrm{ME}$} \\
\hline \multirow[t]{2}{*}{13} & 2650 & $94.2^{\mathrm{ab}}$ & $92.2^{\mathrm{d}}$ & 111.7 & $99.4^{\mathrm{cd}}$ & $9.15^{\mathrm{b}}$ & $3.34^{\mathrm{c}}$ & 3.60 & $4.44^{\mathrm{b}}$ \\
\hline & 2700 & $87.3^{c}$ & $98.0^{\mathrm{c}}$ & 105.7 & $97.0^{\mathrm{d}}$ & $7.81^{\mathrm{c}}$ & $3.81^{\mathrm{a}}$ & 3.48 & $4.43^{\mathrm{b}}$ \\
\hline \multirow[t]{2}{*}{14} & 2650 & $92.6^{\mathrm{bc}}$ & $101.7^{\mathrm{abc}}$ & 109.8 & $101.4^{\mathrm{abc}}$ & $6.30^{\mathrm{de}}$ & $3.41^{\mathrm{ab}}$ & 3.39 & $4.02^{\mathrm{d}}$ \\
\hline & 2700 & $93.2^{\mathrm{bc}}$ & $102.2^{\mathrm{ab}}$ & 113.2 & $102.8^{\mathrm{ab}}$ & $6.92^{\mathrm{d}}$ & $3.55^{\mathrm{b}}$ & 3.70 & $4.30^{\mathrm{bc}}$ \\
\hline \multirow[t]{2}{*}{15} & 2650 & $99.9^{\mathrm{a}}$ & $103.3^{\mathrm{a}}$ & 106.2 & $103.2^{\mathrm{a}}$ & $13.04^{\mathrm{a}}$ & $3.93^{\mathrm{a}}$ & 3.07 & $5.06^{\mathrm{a}}$ \\
\hline & 2700 & $95.2^{\mathrm{ab}}$ & $98.8^{\mathrm{bc}}$ & 107.2 & $100.4^{\mathrm{bc}}$ & $6.19^{\mathrm{e}}$ & $3.47^{\mathrm{ab}}$ & 3.66 & $4.17^{\mathrm{cd}}$ \\
\hline \multicolumn{2}{|c|}{ SE mean } & 1.96 & 1.17 & 2.71 & 0.82 & 0.21 & 0.06 & 0.12 & 0.06 \\
\hline
\end{tabular}

$a, b, c$ :means in the same column bearing different superscripts are significantly different $(p \leq 0.05)$

Table (7): Egg quality of local Sinai hens as a subsequent effect to grower fed diets contained different levels of $\mathrm{CP}$ and $\mathrm{ME}$

\begin{tabular}{lcccccc}
\hline Variable & \multicolumn{5}{c}{ Egg quality traits } \\
\cline { 2 - 7 } \multicolumn{1}{c}{ Factors } & $\begin{array}{c}\text { Shape } \\
\text { index }\end{array}$ & Yolk \% & Albumin \% & Shell \% & $\begin{array}{c}\text { Shell } \\
\text { Thick. }\end{array}$ & Haugh units \\
\hline Crude protein (CP) \% & & & & & \\
13 & 0.227 & 36.95 & 64.16 & 11.82 & $0.288^{\mathrm{b}}$ & 95.33 \\
14 & 0.220 & 36.54 & 63.20 & 10.72 & $0.291^{\mathrm{b}}$ & 99.35 \\
15 & 0.223 & 37.23 & 65.75 & 11.69 & $0.321^{\mathrm{a}}$ & 97.13 \\
SE mean & 0.01 & 0.78 & 1.71 & 0.58 & 0.01 & 2.48 \\
Metabolizable energy (ME) Kcal/ kg diet & & & & & \\
2650 & 0.223 & 37.14 & 65.31 & $10.66^{\mathrm{b}}$ & $0.292^{\mathrm{b}}$ & 96.63 \\
\hline
\end{tabular}

The $16^{\text {th }}$ Scientific Conference for Animal Nutrition, Luxor-Aswan, $28^{\text {th }}$ Nov. $-1^{\text {th }}$ Dec., 2017 
Egyptian J. Nutrition and Feeds (2017), 20 (2)Special Issue

\begin{tabular}{|c|c|c|c|c|c|c|c|}
\hline \multicolumn{2}{|c|}{2700} & 0.224 & 36.67 & 63.43 & $12.16^{\mathrm{a}}$ & $0.307^{\mathrm{a}}$ & 97.91 \\
\hline \multicolumn{2}{|c|}{ SE mean } & 0.004 & 0.64 & 1.39 & 0.48 & 0.006 & 2.02 \\
\hline \multicolumn{8}{|c|}{ Interaction between $\mathrm{CP}$ and $\mathrm{ME}$} \\
\hline \multirow[t]{2}{*}{13} & 2650 & 0.231 & 37.23 & 66.32 & 11.06 & 0.275 & 94.26 \\
\hline & 2700 & 0.223 & 36.67 & 62.00 & 12.58 & 0.300 & 96.40 \\
\hline \multirow[t]{2}{*}{14} & 2650 & 0.219 & 37.10 & 64.18 & 9.69 & 0.283 & 98.23 \\
\hline & 2700 & 0.220 & 35.99 & 62.21 & 11.74 & 0.298 & 100.47 \\
\hline \multirow[t]{2}{*}{15} & 2650 & 0.217 & 37.09 & 65.42 & 11.23 & 0.318 & 97.40 \\
\hline & 2700 & 0.228 & 37.6 & 66.08 & 12.15 & 0.322 & 96.86 \\
\hline \multicolumn{2}{|c|}{ SE mean } & 0.007 & 1.10 & 2.42 & 0.82 & 0.01 & 3.50 \\
\hline
\end{tabular}

Table (8): Economic efficiency of local Sinai laying hens as a subsequent effect to grower fed diets contained different levels of $\mathrm{CP}$ and $\mathrm{ME}$

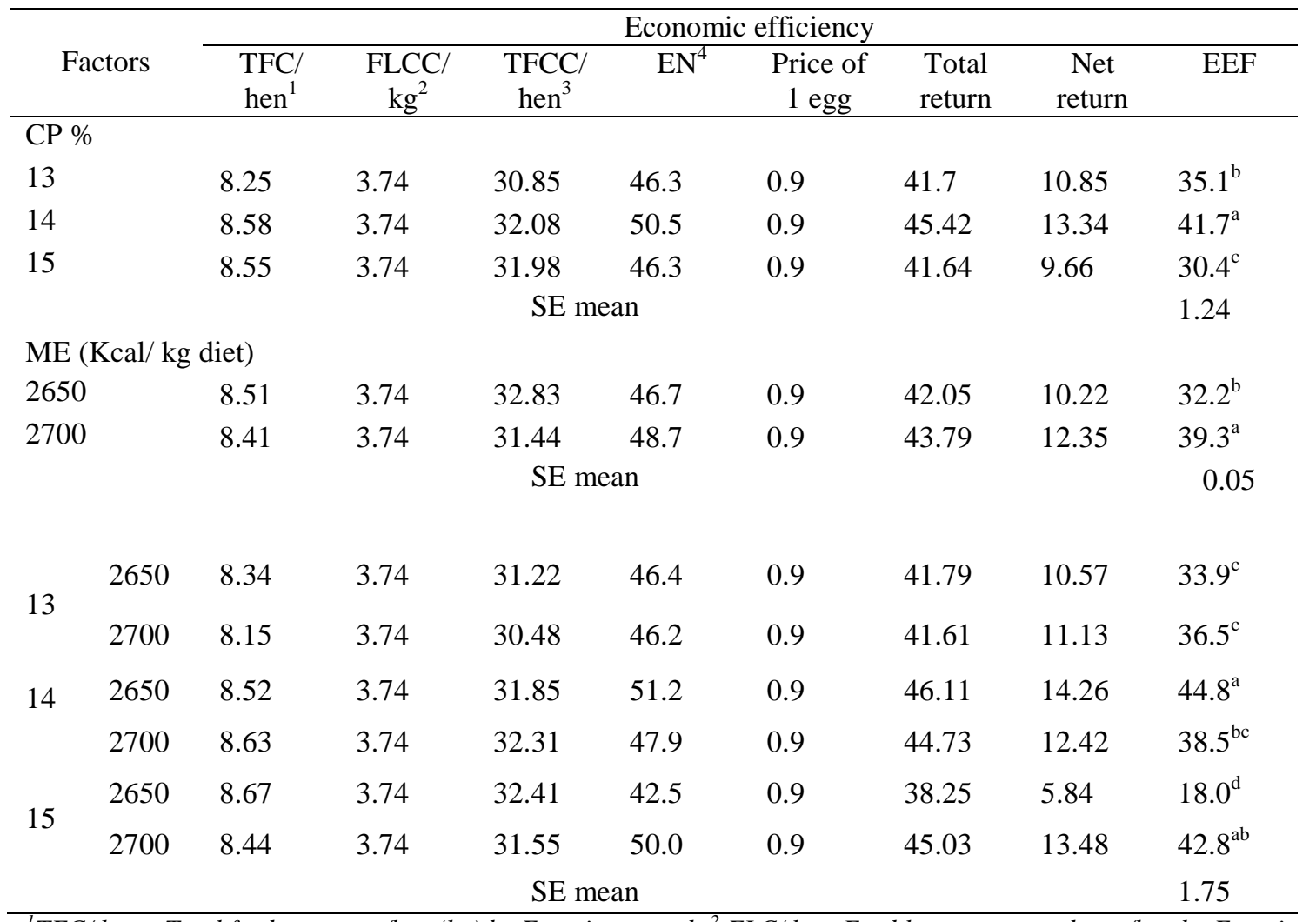

${ }^{T}$ TFC/ hen = Total feed consume /hen ( $\mathrm{kg}$ ) by Egyptian pound $;{ }^{2} \mathrm{FLC} / \mathrm{kg}=$ Feed layer consumed cost/hen by Egyptian pound $;{ }^{3}$ TFCC/ hen =Total feed consumed cost /hen by Egyptian pound; $E N^{4}=$ Egg number/hen;

$a, b, c:$ means in the same column bearing different superscripts are significantly different $(p \leq 0.05)$

\section{REFERENCES}

Association of Official Analytical Chemists (AOAC) (1990). Official methods of analysis. $13^{\text {th }}$ Ed. Published by the AOAC., Washington, D.C., USA.

Bohnsack, C.R.; R.H. Harms; W.D. Merkel and G.B. Russell (2002). Performance of commercial layers when fed diets with four content of corn oil or poultry fat. Applied Poultry Research, 11: 68-76.

Candrawati,D.P.M.A. (1999). Pendugaan Kebutuhan Energi dan Protein Ayam Kampung Umur 0-8 Minggu. Tesis Magister Sains .Institut Pertanian Bogor, Bogor. 


\section{Beshara et al.}

Choprakarn, K.; I. Salangam; C. Boonman and W. Kaewleun (2002). Effect of protein levels and stocking densities on performance and carcass composition of Thai indigenous chickens. J. ISSAAA, 7:1-8.

Chemjor, W. (1998). Energy and protein requirements of indigenous chickens of Kenya Msc thesis, Egerton University, Kenya, pp. 83

Chinrasri, A. (2004). Poultry Production Technology. Apichart Printing Press, Mahasarakam Province, Thailand. pp 206

Dewi, G.A.; M.K, I.K. Astiningsih; R.R. Indrawati; I.M. Laksmiwati and I.W. Siti. (2010). Effect of balance energy-protein ration for performance of kampung chickens. Pp. 23 - 24. In: Proceedings of Bioscience and Biotechnology Conference. University of Udayana, Bali.

Dublecz, K.; L. vincze; G. Szuts; L. Wagner; L. Pal and A. Bartos (1999). Effect of dietary energy level on the performance of broiler chicks. Proceedings 12th European Symposium on Poultry Nutrition. WPSA-Velthoven, The Netherlands, 15-19 August 1999. pp: 424-426.

Duncan, D.B. (1955). Multiple ranges and multiple f- test, Biometries 11: 1-42.

Grobas, S.; J. Mendez; C. Deblas and G.G. Mateos (1999). Laying hen productivity as affected by energy, supplemental fat, and linoleic acid concentration of the diet. Poultry Science Journal, 78: 1542- 1551.

Feed Composition Tables For Animal and Poultry Feedstuffs Used In Egypt, (2001). Technical builetin No, 1, Center Lab Feed and Food; Ministry of Agriculture, Egypt.

Gonzalez-A, M.J. and G.M. PESTI (1993). Evaluation of the protein to energy ratio concept in broiler and turkey nutrition. Poultry Science Journal. 72:2115-2123.

Henrichs, J. and H. Steinfeld (2007). Feed availability inducing structural change in poultry sector. In Poultry in the 21st Century, http:// www. fao. Org / Ag / againfo/home/events/bangkok

King'ori, A.M., J.K. Tuttoek; H.K. Muiruri and A.M. Wachira (2003). Protein requirements of growing indigenous chicken during the 14-21 weeks growing period. South Africa Journal Animal Science.Volume 33, No 2. page:78- 82.

Kout Elkoloub, M.El.Moustafa; A.L. Awad and A.I.Ai Ghonim (2010). Response of domyayi ducklings to diets containing different levels of metabolizable energy and crude protein 1- during growth period. Egypt. Poult. Sci. Vol (30) (II): 535-564.

Lesson, S. and J.D. Summers (2001). Scoots Nutritional of the chicken. University book. Guelph, Canada.

Lewis, P.D.; M.G. Macleod and G.C. Perry (1994). Effects of lighting regimen and grower diet energy concentration on energy expenditure, fat deposition and body weight gain of laying hens. British Poultry Science, 35: (3) 407- 415.

Lippense, M.; G. Huy ghbaert and Degroote, G. (2002). The efficiency of nitrogen retention during compensatory growth of food restricted broilers. British Poultry Science Journal, 43: 669- 676.

Maiorka, A.; A.V.F. Da Silva; E. Santin; J.M. Pizauro Jr and M. Macari (2004). Broiler breeder and dietary energy level on performance and pancreas lipase and trypsin activities of 7-days old chicks. Int. J. Poult. Sci., 3:234-237.

Nahashon S.N.; N. Adefope; A. Amenyenu and D. Wright (2006). Effect of varying metabolizable energy and crude protein concentrations in diets of Pearl Gray Guinea Fowl Pullets 1- Growth performance.Poult. Sci., 85: 1847-1854

Ndegwa, J.M.; R. Mead; P. Norrish; C.W. Kimani and A.M. Wachira (2001). The performance of indigenous Kenya chickens fed diets containing different protein levels during rearing. Tropical Animal Health and Production 33: 441-448.

Novak, C.; H. Ykout and S. Scheideler (2004). The combined effects of dietary lysine and total sulfer acid level on egg production parameters and egg components in Dekalb Delta laying hens. Poultry Science Journal, 83: 977- 984.

NRC (1994). National Research Council. Nutrient Requirement for Poultry. Ninth Revised Ed. National Academy Press, USA.

Payne, W.J.A. (1990). An introduction to Animal Husbandry in the Tropics, $4^{\text {th }}$ edition: 684-744. (Essex and New York, Longman Scientific and Technical). 
Pinhriro, D.F.; V.C. Cru; J.R. Sartori and M.L.M. Panlino (2004). Effect of early feed restriction and enzyme supplementation on digestive enzyme activities in broilers. Poultry Science Journal, 83: 15441550.

Plavnik, I.; E. Wax; D. SKLAN; I. Bartov and S. Hurwitz (1997). The response of broiler chickens and turkey poults to dietary energy supplied either by fat or carbohydrates. Poultry Science 76: 10001005.

Prachya, P.; C. Noppawan and T. Nonthanavongs (1994). Effect of dietary protein and energy levels on performance of Native-Shanghai chickens. Petchaburi Animal Nutrition Research Centre. Research Project No. 34-1326-58.

Skiner-Nober, D.O.; J.G. Berry and R.G. Teeter (2001). Use of a single diet feeding program for female broiler. Animal Science research report Oklahoma University.

Sohail, S.S.; M.M. Bryant and D.A. Rolannd (2003). Influence of dietary fat on economic return of commercial leghorns. Journal of Applied Poultry Research, 12: 356- 361.

Smith, A.J. (1990). The integration of rural production into the family food security system. CTA Seminar proceedings on Smallholder rural Poultry production $9-13$ October, 1990. Thessaloniki, Greece

SPSS, (2008). SPSS User's Guide Statistics. Ver. 17. Copyright SPSS Inc., USA.

Tadelle, D. and B. Ogle (2000). Nutritional status of village poultry in the central highlands of Ethiopia as assessed by analyses of crop contents. Ethiopian Journal of Agricultural Science 17: 47-57.

Tuan, V.N.; C. Bunchasak and S. Chantsavang (2010). Effects of dietary protein and energy on growth performance and carcass characteristics of betong chickens (Gallus domesticus) during growing period. International Journal of Poultry Science 9 (5): 468-472.

Novak, C.L.; H.M. Yakout and J. Remus (2007). Response to varying dietary energy and protein with or without enzyme supplementation on growth and performance of Leghorns: Growing period. Journal Applied Poultry Research 16:481-493.

Veldkamp, T.; R.P. Kwakkel; P.R. Ferket and M.W.A. Verstegen (2005). Growth response to dietary energy and lysine at high and low ambient temperature in male turkeys. Poultry Science Journal 84: 273-282.

Wu, M.; M. Brynt; R.A. Voilet and D.A. Roland (2005). Effect of dietary energy on performance and egg composition of bovans white and dekalb whit hens during phase I. Poultry Science Journal, 84: 16101615.

Zhao, F; S. S. Hou; H. F. Zhang and Z. Y. Zhang (2007). Effects of dietary metabolizable energy and crude protein content on the activities of digestive enzymes in jejunal of Pekin ducks. 


\title{
Beshara et al.
}

تأثير مستويات مختلفة من البروتين الخام والطاقة الممثلة علي الأداء الإنتاجي للاجاج المحلي خلال فترة النمو والتأثير اللاحق خلال فترة انتاج البيض منتل البرونين

\author{
ملاك منصور بثاره ، قوت القلوب مصطفي السيد مصطفي ، مجدي أحمد عوض حسين، محمد جاد الحق قاسم، عبد \\ الرحيم عبده عبد الباسط ريحان

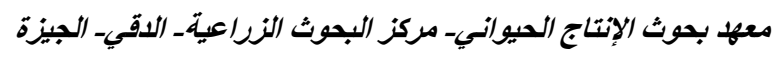

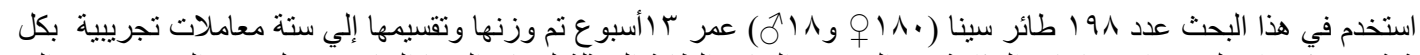

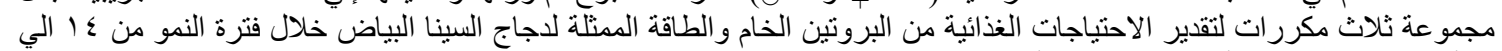

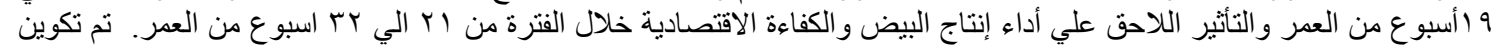

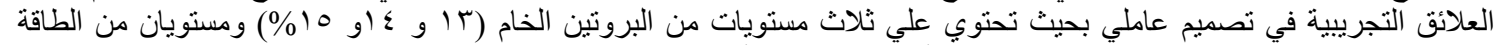

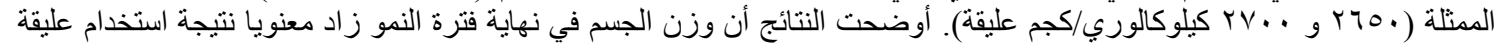

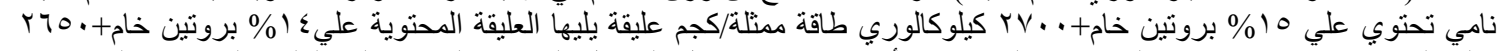

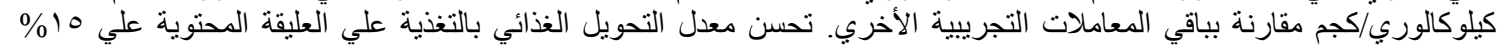

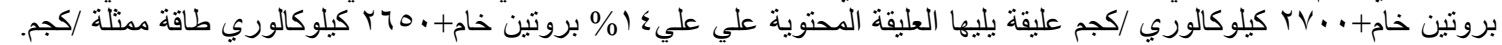

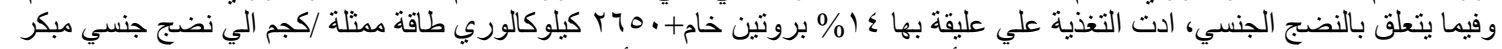

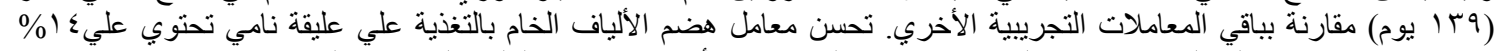

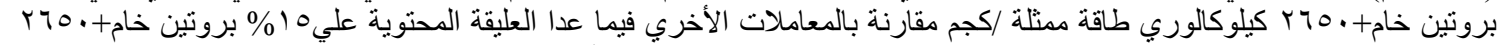

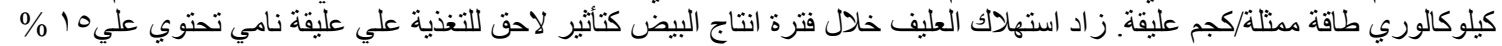

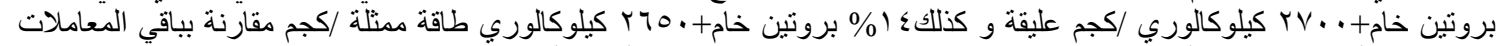

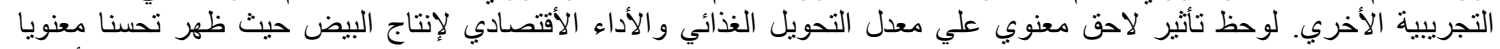

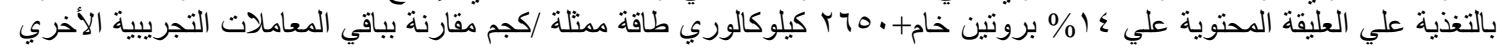

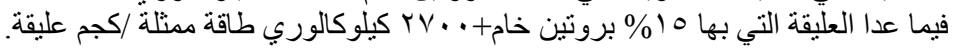

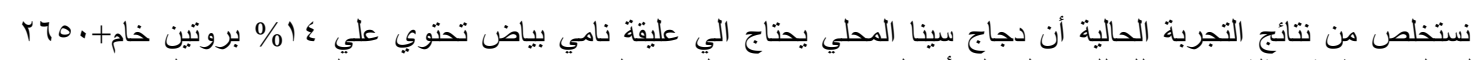

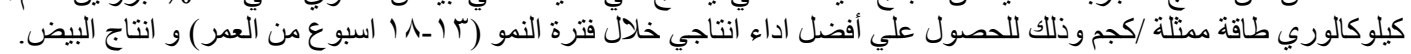

